\title{
ANALISIS BERPIKIR KRITIS SISWA DALAM PEMECAHAN MASALAH MATEMATIKA PADA MATERI LINGKARAN
}

\author{
Nurul Khasanah ${ }^{1)}$,Tomi Listiawan ${ }^{2)}$, Mugianto ${ }^{3)}$ \\ ${ }^{1)}$ nurul.kh@gmail.com, ${ }^{2)}$ tomi@ $@$ stkippgritulungagung.ac.id, ${ }^{3)}$ mugianto@ stkippgritulungagung.ac.id \\ ${ }^{1,2,3)}$ STKIP PGRI Tulungagung
}

\begin{abstract}
Abstrak
Berpikir kritis adalah sebuah proses sistematis yang memungkinkan peserta didik untuk merumuskan dan mengevaluasi keyakinan dan pendapat mereka sendiri. Berdasarkan hasil penelitian kemampuan berpikir kritis siswa kelas VIII-A dalam menyelesaikan masalah matematika dengan subjek penelitian siswa kelas VIII-A MTs Sunan Kalijogo tahun pelajaran 2015/ 2016 hanya sampai pada tingkat kemampuan berpikir kritis 3 (kritis). Masing-masing tingkat kemampuan berpikir kritis (TKBK) memiliki karakteristik tertentu berkaitan dengan elemen bernalar dan standar intelektual bernalarnya.
\end{abstract}

Kata kunci : berpikir kritis, pemecahan masalah

\section{PENDAHULUAN}

Beberapa tahun terakhir berpikir kritis telah menjadi suatu istilah yang sangat populer dalam dunia pendidikan. Karena berpikir kritis memungkinkan peserta didik untuk menemukan kebenaran di tengah banjir kejadian dan informasi yang mereka hadapi setiap hari (Fachrurazi, 2011:80). Berpikir kritis juga membantu peserta didik untuk bisa bertahan dalam perkembangan zaman saat ini. Kata kritis berasal dari bahasa Yunani yaitu kritikos dan kriterion (Paul, dkk dalam Lambertuse, 2009:137). Kata kritikos berarti pertimbangan sedangkan kriterion mengandung makna ukuran baku atau standar. Sehingga secara etimologi, kata kritis mengandung makna pertimbangan yang didasarkan pada suatu ukuran baku atau standar. Dengan demikian secara etimologi berpikir kritis mengandung makna suatu kegiatan mental yang dilakukan seseorang untuk dapat memberi pertimbangan dengan menggunakan ukuran atau standar tertentu.

Kemampuan berpikir (thinking skill) merupakan salah satu penentu dalam proses pembelajaran. Apabila anak-anak diberi kesempatan untuk menggunakan pemikiran dalam tingkatan yang lebih tinggi, pada akhirnya mereka akan terbiasa membedakan kebenaran dan kebohongan, penampilan dan kenyataan, fakta, dan opini serta pengetahuan dan keyakinan. Secara alami mereka akan membangun argumen dengan menggunakan bukti yang dapat dipercaya dan logika yang masuk akal (Johnson 2, 2007: 184). Kegiatan berpikir seperti inilah yang diharapkan dalam pembelajaran matematika.

Kemampuan berpikir kritis mengandung makna sebagai kesiapan dalam pengambilan keputusan yang penuh pertimbangan (Lloyd, 2010: 2). Berpikir kritis adalah sebuah proses sistematis yang memungkinkan peserta didik untuk merumuskan dan mengevaluasi keyakinan dan pendapat mereka sendiri (Fachrurazi, 2011: 81). Jadi, berpikir kritis itu bukan hanya tindakan sederhana menerima informasi dan kemudian siap menerimanya, tapi berpikir kritis melibatkan proses berpikir aktif dan menganalisis apa yang diterima.

Kemampuan berpikir kritis merupakan salah satu modal dasar atau modal intelektual yang sangat penting bagi setiap orang dan merupakan bagian yang fundamental dari kematangan manusia (Liliasari, 2001:55-56). Oleh karena itu, kemampuan berpikir kritis sangat penting bagi peserta didik di setiap jenjang pendidikan. Hal ini sesuai dengan prioritas pembangunan pendidikan yang tertera dalam Kurikulum Tingkat Satuan Pendidikan (KTSP) di mana peserta didik diharapkan dapat berpikir matematis, yaitu berpikir logis, analitis, sistematis, kritis, kreatif serta kemampuan bekerja sama (Lambertuse, 2009:136).

Berpikir kritis adalah suatu proses mental yang melibatkan pengetahuan, keterampilan bernalar, dan karakter bernalar intelektual bernalar. Pemikiran yang seperti 
inilah yang diperlukan dalam pembelajaran matematika, terutama dalam memahami konsepnya. Pada dasarnya untuk belajar matematika diperlukan kemampuan berpikir tingkat tinggi, dengan kata lain belajar matematika dapat merasuk dengan dalam hingga ke inti sarinya adalah menggunakan kemampuan berpikir kritis. Begitu juga sebaliknya, kemampuan berpikir kritis dapat dilatih dan dibiasakan kepada peserta didik dengan melalui pembelajaran matematika. Dimana kemampuan berpikir kritis dan pembelajaran matematika tidak dapat dipisahkan. Pada penelitian ini, untuk mempermudah penilaian dari kemampuan berpikir kritis digunakanlah model Paul dan Elder.

Paul dan Elder merupakan pakar berpikir kritis dalam tradisi filosofis yang menyusun suatu model berpikir kritis dengan nama populer yaitu Model Berpikir Kritis Paul dan Elder. Menurut Paul dan Elder, ada 3 macam komponen berpikir kritis yaitu (1) elemen bernalar, (2) standar intelektual bernalar dan (3) karakter intelektual bernalar.

Dari ketiga komponen berpikir kritis menurut Paul dan Elder, dapat kita pelajari bahwasanya melatih berpikir kritis kepada peserta didik itu tidaklah mudah, karena berpikir kritis seseorang tidak serta merta dapat langsung diketahui hasilnya. Di mana untuk mengembangkan kemampuan berpikir kritis peserta didik harus melalui berbagai proses yang dapat dilihat hubungannya dari standar intelektual bernalar, elemen bernalar dan karakter intelektual bernalar.

Namun, pada dasarnya untuk kemampuan berpikir kritis Paul dan Elder membaginya menjadi 6 tingkatan, yaitu (1) berpikir yang tidak direfleksikan (unreflective thinking), (2) berpikir yang menantang (challenged thinking), (3) berpikir permulaan (beginning thinking), (4) berpikir latihan (practicing thinking), (5) berpikir lanjut (advanced thinking), dan (6) berpikir yang unggul (master thinking). Di mana jika sesuai dengan tingkatan berpikir kritis Paul dan Elder, maka perkembangan berpikir seseorang merupakan suatu proses yang bertahap dan menempatkan seseorang pada tingkatan tertentu serta membutuhkan waktu yang lama (bertahun-tahun) (Kurniasih, 2010:41-42). Oleh karena itu, analisis kemampuan berpikir kritis dalam penelitian ini tidak menggunakan tingkat kemampuan berpikir kritis Paul dan Elder melainkan hanya menggunakan elemen bernalar dan standar intelektual bernalar dari Model berpikir kritis Paul dan Elder.

Agar terpenuhi tujuan dari pembelajaran matematika di sekolah, maka perlu memberikan pembelajaran berpikir tingkat tinggi kepada peserta didik (Listiawan, 2014). Berpikir tingkat tinggi perlu diberikan dalam berbagai lingkungan belajar, baik konvensional maupun berbasis teknologi (Listiawan, 2015).Berpikir tingkat tinggi yang sangat diperlukan dalam pembelajaran matematika adalah berpikir kritis. Karena berpikir kritis merupakan suatu pemikiran yang ideal dengan tujuan untuk bisa memberikan pemahaman yang mendalam kepada peserta didik. Bahkan dengan berpikir kritis pelajaran matematika dapat dipahami hingga ke akar-akarnya. Selain itu, siswa dalam melakukan suatu hal akan lebih terarah dan menjadi kebiasaan yang baik guna memahami konsep matematika, memecahkan masalah, mengambil kesimpulan dan mengevaluasi hasil pemikiran secara matang.

Berpikir kritis dalam matematika akan muncul jika peserta didik memiliki keinginan untuk menemukan jawaban dan mencapai pemahaman. Pemikir yang kritis akan meneliti proses berpikir mereka sendiri dan proses berpikir orang lain untuk mengetahui apakah proses berpikir yang mereka lakukan masuk akal (Johnson 2, 2007:187). Karena itu, berpikir kritis dalam matematika akan menjadikan peserta didik mampu mengorganisasi dan menggabungkan berpikir matematis melalui komunikasi, mengkomunikasikan berpikir matematisnya secara koheren dan jelas kepada peserta didik yang lain, menganalisis dan mengevaluasi berpikir matematis dan strategi, menggunakan bahasa matematika untuk mengekspresikan ide-ide matematis dengan tepat (Kurniasih, 2010:47). 
Berpikir kritis dapat terjadi melalui suatu tahapan berpikir. Sesuai dengan kalimat tersebut Perkins \& Murphy (dalam Kurniasih, 2010:56-57) membagi tahap berpikir kritis dalam matematika menjadi 4 tahap yaitu : (1) Tahap klarifikasi (clarification). Tahap ini merupakan tahap menyatakan, mengklarifikasi, menggambarkan (bukan menjelaskan) atau mendefinisikan masalah. Aktivitas yang dilakukan adalah menyatakan masalah, menganalisis pengertian dari masalah, mengidentifikasi sejumlah asumsi yang mendasari, mengidentifikasi hubungan di antara pernyataan atau asumsi, mendefinisikan atau mengkritisi definisi pola-pola yang relevan.

(2) Tahap asesmen (assesment). Tahap ini merupakan tahap menilai aspek-aspek seperti membuat keputusan pada situasi, mengemukakan fakta-fakta argumen atau menghubungkan masalah dengan masalah yang lain. Pada tahap ini digunakan beragam fakta yang mendukung atau menyangkal. Aktivitas yang dilakukan adalah menyediakan atau bertanya apakah penalaran yang dilakukan valid, penalaran yang dilakukan relevan, menentukan kriteria penilaian seperti kredibilitas sumber, membuat penilaian keputusan berdasarkan kriteria penilaian atau situasi atau topik, memberikan fakta bagi pilihan kriteria penilaian.

(3) Tahap penyimpulan (inference). Tahap ini menunjukkan hubungan antara sejumlah ide, menggambarkan kesimpulan yang tepat, menggeneralisasi, menjelaskan (bukan menggambarkan) dan membuat hipotesis. Aktivitas yang dilakukan antara lain membuat kesimpulan yang tepat dan membuat generalisasi.

(4) Tahap strategi/ taktik (strategy/ tactic). Tahap ini merupakan tahap mengajukan, mengevaluasi sejumlah tindakan, menggambarkan tindakan yang mungkin, mengevaluasi tindakan dan memprediksi hasil tindakan.

Dalam penelitian ini, untuk menganalisis tingkat kemampuan berpikir kritis siswa dalam pemecahan masalah matematika menggunakan Model Berpikir Kritis Paul dan Elder, yaitu elemen bernalar dan standar intelektual bernalar saja. Dalam hal ini karakter intelektual bernalar tidak digunakan karena karakter tidak bisa diteliti dengan mudah dan memerlukan waktu yang lama minimal 1 semester. Tingkat kemampuan berpikir kritis disingkat menjadi TKBK disusun secara diskrit yaitu $0,1,2,3$, dan 4 .

Peserta didik dikelompokkan ke dalam masing-masing tingkatan berpikir kritis yaitu tingkat kemampuan berpikir kritis 0 (TKBK 0 ), tingkat kemampuan berpikir kritis 1 (TKBK 1), tingkat kemampuan berpikir kritis 2 (TKBK 2), tingkat kemampuan berpikir kritis 3 (TKBK 3), dan tingkat kemampuan berpikir kritis 4 (TKBK 4). Tingkat berpikir paling rendah (TKBK 0) adalah keterampilan menghafal (recall thinking) yang terdiri atas keterampilan yang hampir otomatis atau refleksif. Tingkat berpikir selanjutnya adalah keterampilan dasar (basic thinking) atau TKBK 1. Keterampilan ini meliputi memahami konsep-konsep seperti penjumlahan, pengurangan dan sebagainya termasuk aplikasinya dalam soal-soal. Keterampilan yang selanjutnya adalah TKBK 2. Salah satu kemampuan berpikir yang tergolong ke dalam kemampuan berpikir tingkat tinggi adalah kemampuan berpikir kritis (TKBK 3 dan TKBK 4). Kriteria TKBK yang disesuaikan dengan indikator berpikir kritis menurut Ennis (1993) yaitu mampu: (1) merumuskan pokokpokok permasalahan; (2) mengungkap fakta yang ada; (3) memilih argumen yang logis; (4) mendeteksi bias dengan sudut pandang yang berbeda; (5) menarik kesimpulan.

Dari pemaparan di atas, agar peserta didik mampu memecahkan masalah matematika pada materi lingkaran maka pendidik harus bisa menganalisis dan mengeksplor kemampuan berpikir kritis peserta didik. Karena tujuan dari berpikir kritis adalah untuk mencapai pemahaman yang mendalam(Johnson 2, 2007: 185).Sehingga pendidik dan peserta didik dapat melaksanakan pembelajaran yang sesuai dengan tujuan pendidikan nasional. Selain itu, materi matematika dan keterampilan berpikir kritis merupakan dua hal yang tidak dapat 
dipisahkan karena materi matematika dipahami melalui berpikir kritis dan berpikir kritis dilatih melalui belajar matematika(Lambertuse, 2009: 137).

Pada penelitian ini sekolah yang akan menjadi subjek penelitian adalah MTs Sunan Kalijogo, berdasarkan hasil observasi kemampuan berpikir kritis belum mendapat perhatian, oleh karena itu tujuan penelitian iniadalah untuk mendeskripsikan tingkat berpikir kritis siswa dalam menyelesaikan masalah matematika.

\section{METODE PENELITIAN}

Dalam penelitian ini kehadiran peneliti mutlak diperlukan karena peneliti merupakan instrumen utama (Ibid, 9). Peneliti sebagai instrumen utama yang dimaksud adalah peneliti bertindak sebagai pengamat, pewawancara, pengumpul data, sekaligus pembuat laporan sehingga kehadiran peneliti mutlak diperlukan. Oleh karena itu, peneliti bekerjasama dengan pihak sekolah mulai dari kepala sekolah, guru dan siswa khususnya kelas VIII untuk mengumpulkan data sebanyak-banyaknya.

Data dalam penelitian ini adalah hasil pekerjaan siswa dalam mengikuti tes dan hasil wawancara yang digunakan peneliti untuk menganalisis tingkat kemampuan berpikir kritis yang telah dicapai oleh siswa. Data penelitian berupa tingkat kemampuan berpikir kritis siswa dalam menyelesaikan masalah matematika pada materi lingkaran disusun secara diskrit yaitu $0,1,2,3,4$, berdasarkan elemen bernalar dan standar intelektual bernalar dari model berpikir Kritis Paul \& Elder.

Sumber data dalam penelitian ini adalah siswa kelas VIII MTs Sunan Kalijogo terdiri dari 29 siswa. Seluruh siswa diberikan soal tes dan kemudian diambil 5 siswa untuk dijadikan subjek penelitian.

Teknik pengumpulan data adalah teknik yang sistematik dan standar untuk memperoleh data yang diperlukan (Arikunto, 2010:265). Adapun teknik pengumpulan data dalam penelitian ini, adalah sebagai berikut. Bentuk tes yang digunakan dalam penelitian ini adalah tes essay (uraian) karena dapat mempermudah peneliti dalam membantu penentuan subjek penelitian.

Wawancara dilaksanakan setelah akhir tes terhadap siswa terpilih untuk mengetahui tingkat kemampuan berpikir kritis siswa dalam menyelesaikan masalah matematika pada materi lingkaran.

Dalam penelitian ini peneliti menggunakan alat perekam suara dan gambar untuk mempermudah peneliti dalam pengambilan data. Selain itu peneliti juga menggunakan alat tulis untuk memback-up wawancara dan juga untuk merekam data yang selain suara yang tidak dapat direkam oleh alat perekam suara selama wawancara berlangsung. Wawancara dalam penelitian ini digunakan untuk menggali data-data guna memperjelas data hasil tes yang tidak semuanya dapat dijelaskan melalui analisa hasil jawaban siswa. Dalam wawancara ini, peneliti mencoba melihat kembali proses berpikir kritis siswa ketika mengerjakan tes ini melalui pernyataan yang diungkapkan siswa selama pelaksanaan wawancara.

Agar mendapatkan hasil yang maksimal dalam penelitian ini, maka peneliti perlu melakukan validasi ahli terhadap instrumen yang akan digunakan. Karena instrumen penelitian sangat erat kaitannya dengan penilaian akhir atau evaluasi dalam suatu penelitian. Mengevaluasi adalah memperoleh data tentang status sesuatu dibandingkan dengan standar atau ukuran yang telah di tentukan (Arikunto, 2010:193). Sehingga, sebelum instrumen diberikan kepada subjek, maka perlu di cek dan disyahkan oleh validator ahli. Dimana validator ahli terdiri dari dosen prodi pendidikan matematika dan guru mata pelajaran matematika dari sekolah yang dijadikan tempat penelitian.

Adapun instrumen utama yang digunakan dalam penelitian ini adalah peneliti sendiri (Moleong, 2011:14). Instrumen pendukungnya adalah sebagai berikut.

a) Pedoman wawancara, yaitu alat bantu yang digunakan peneliti ketika mengumpulkan data melalui tanya-jawab dengansiswa guna mengetahui target penyelidikan, 
b) Lembar soal, yaitu alat bantu yang berupa tes tertulis mengenai materi lingkaran.

Tes tertulis ini berupa tes uraian yang berjumlah 3 soal. Soal tes yang digunakan adalah soal-soal untuk memacu berpikir kritis yang diambil dari buku paket matematika kelas VIII mengenai materi lingkaran.

Dalam penelitian ini, untuk menganalisis tingkat kemampuan berpikir kritis siswa dalam pemecahan masalah matematika menggunakan model berpikir kritis Paul \& Elder, yaitu elemen bernalar dan standar intelektual bernalar saja. Sedangkan karakter intelektual bernalar tidak digunakan karena karakter tidak bisa diteliti dengan mudah dan memerlukan waktu yang lama minimal 1 semester. Tingkat kemampuan berpikir kritis disingkat menjadi TKBK disusun secara diskrit yaitu $0,1,2,3$, dan 4. Berdasarkan TKBK tersebut, peserta didik dikelompokkan kedalam masing-masing tingkat sesuai dengan karakteristik yang telah disusun.

Adapun proses analisa data yang dilakukan mengadopsi dan mengembangkan pola interaktif yang dikembangkan oleh Milles \& Hiberman (dalam Sugiyono, 2009:337-345), yaitu Reduksi Data.

Reduksi data merupakan suatu kegiatan proses pemilihan, pemusatan perhatian pada penyederhanaan, pengabstrakan dan transformasi data mentah yang didapat dari catatan-catatan tertulis dilapangan. Reduksi data dimulai pada awal kegiatan penelitian sampai dilanjutkan selama kegiatan pengumpulan data dilaksanakan. Dengan reduksi data ini tidak perlu mengartikannya secara kuantifikasi. Data kualitatif dapat disederhanakan dan di transformasikan dalam aneka macam cara seperti melalui seleksi ketat, ringkasan/ uraian singkat, menggolongkannya dalam satu pola yang lebih besar dan lain sebagainya.

Penyajian data merupakan proses penyusunan informasi secara sistematis dalam rangka memperoleh kesimpulan sebagai temuan penelitian dan pengambilan tindakan. Dalam penelitian ini data yang didapat berupa hasil tes pekerjaan siswa, kalimat, kata-kata yang berhubungan dengan fokus penelitian di susun dalam bentuk tabel, kata-kata yang urut sehingga sajian data yang merupakan sekumpulan informasi yang tersusun secara sistematis dapat memberikan kemungkinan untuk ditarik kesimpulan.

Pada saat kegiatan analisis data yang berlangsung secara terus menerus selesai dikerjakan, baik yang berlangsung di lapangan maupun setelah selesai di lapangan, langkah selanjutnya adalah melakukan penarikan kesimpulan. Untuk mengarah pada hasil kesimpulan ini tentunya berdasarkan dari hasil analisis data yang berasal dari tes dan wawancara.

Keabsahan atau kebenaran data merupakan hal yang penting dalam penelitian. Oleh karena itu, untuk bisa memperoleh data yang valid maka penulis melakukan hal-hal sebagai berikut (Moleong, 2011:327-333):

Ketekunan/Keajegan Pengamatan. Keajegan pengamatan berarti mencari secara konsisten interprestasi dengan berbagai cara dalam kaitan dengan proses analisis yang konstan atau tentatif. Di mana peneliti secara terbuka dan terjun langsung dalam mengadakan penelitian dengan teliti dan rinci secara berkesinambungan. (2) Triangulasi, Triangulasi adalah suatu teknik yang bertujuan untuk menjaga keobjektifan dan keabsahan data dengan cara membandingkan informasi data yang diperoleh dari beberapa sumber, sehingga data yang diperoleh merupakan data yang absah. Triangulasi pada penelitian ini dilakukan dengan menggunakan triangulasi metode. Triangulasi metode dilakukan dengan cara membandingkan data hasil tes dengan data hasil wawancara. (3) Pemeriksaan Sejawat Melalui Diskusi, Pengecekan sejawat adalah teknik yang dilakukan dengan cara mengekspos hasil sementara atau hasil akhir yang diperoleh dalam bentuk diskusi dengan rekan-rekan sejawat. Diskusi ini dilakukan dengan dosen pembimbing dengan maksud untuk mendapatkan masukan dari segi metodologi maupun konteks penelitian sehingga data yang diharapkan dalam penelitian tidak menyimpang. Sehingga datadata yang diperoleh benar-benar mencerminkan data yang valid. 


\section{HASIL}

Penelitian dengan judul "Analisis Berpikir Kritis Siswa Dalam Pemecahan Masalah Matematika pada Materi Lingkaran di Kelas VIII MTs Sunan Kalijogo Tulungagung Pelajaran 2015/ 2016" merupakan sebuah penelitian yang dilakukan guna mengetahui tingkatan dari kemampuan berpikir kritis siswa dalam pemecahan masalah matematika terutama pada materi lingkaran. Tingkat kemampuan berpikir kritis siswa ini akan diukur dengan menggunakan elemen bernalar dan standar intelektual bernalar Model Berpikir Kritis dari Paul dan Elder.

Penelitian ini dilaksanakan di MTs Sunan Kalijogo tepatnya dikelas VIII-A, dimana materi lingkaran telah selesai diajarkan pada semester genap ini.Untuk mempermudah dalam pelaksanaan dan analisa data serta untuk menjaga privasi subjek, maka peneliti melakukan pengkodean kepada setiap siswa. Pengkodean siswa dalam penelitian ini didasarkan atas dua bagian yaitu (Inisial) dan (Nomer Absen). Berikut salah satu contohnya: kode siswa AS01 memiliki arti siswa dengan nama Agus Setiawan dan nomer absen 01, begitu juga selanjutnya hingga nomor absen 29.

Dalam pelaksanaannya, materi yang digunakan dalam tes ini adalah materi mengenai lingkaran. Tes ini terdiri dari 3 soal dan dilaksanakan dengan rentang waktu selama 45 menit. Kegiatan ini berlangsung dengan baik dan lancar. Setelah selesai pelaksanaan tes, peneliti menganalisis jawaban siswa dan menentukan siswa yang akan menjadi subjek wawancara. Menganalisis jawaban siswa dengan cara melihat respon hasil jawaban siswa. Respon hasil jawaban siswa ini beracuan pada petunjuk soal dan keunikan jawaban siswa. Di mana keunikan tersebut dipertimbangkan berdasarkan elemen bernalar dan standar intelektual bernalar Model Berpikir Kritis dari Paul dan Elder. Setelah selesai, kemudian peneliti mengambil 5 siswa untuk pelaksanaan wawancara.

Untuk memudahkan dalam memahami dan menganalisa data hasil wawancara maka peneliti merekam hasil wawancara menggunakan alat perekam dan untuk menyimpan kejadian selain suara yang tidak dapat direkam oleh alat perekam peneliti menggunakan alat tulis. Pelaksanaan wawancara ini dilaksanakan di kelas VIII-A MTs Sunan Kalijogo.

Dari penelitian ini, peneliti menemukan sesuatu yang unik yaitu peneliti sebut sebagai temuan penelitian. Dari temuan penelitian yang didasarkan atas paparan data yang telah dijelaskan di atas dapat kita ketahui bahwasanya penelitian mengenai analisis kemampuan berpikir kritis siswa dalam memahami masalah matematika terutama pada materi lingkaran di kelas VIII-A MTs Sunan Kalijogo semester genap tahun ajaran 2015/ 2016 ini mencapai TKBK 3.

Hal ini sesuai dengan penelitian terdahulu yaitu penelitian yang dilakukan oleh Ary Woro Kurniasih (2010) yang menyatakan bahwa tingkat kemampuan berpikir kritis mahasiswa Prodi Pendidikan Matematika FMIPA UNNES dalam menyelesaikan masalah matematika hanya sampai TKBK 3 (kritis) dan tidak sampai pada TKBK 4 (sangat kritis). Namun, meskipun demikian antara penelitian yang dilakukan oleh Ary Woro dengan penelitian yang dilakukan oleh peneliti sekarang ini berbeda, karena peneliti terdahulu menggunakan subjek mahasiswa dan peneliti sekarang menggunakan subjek siswa serta materi yang digunakan berbeda, di mana peneliti terdahulu menggunakan materi konsep dan teorema turunan fungsi sedangkan peneliti sekarang menggunakan materi lingkaran namun lebih dikhususkan adalah pemecahan masalahnya. Selain itu, situasi dan kondisi penelitian yang dilakukan tidak sama.

Pada dasarnya penilaian yang peneliti gunakan untuk mengetahui tahapan kemampuan berpikir kritis siswa kelas VIII-A MTs Sunan Kalijogoadalah sesuai dengan Tingkat Kemampuan Berpikir Kritis Paul dan Elder. Menurut Paul dan Elder, ada 5 tingkat berpikir kritis yaitu TKBK 0 (tidak kritis), TKBK 1 (kurang kritis), TKBK 2 (cukup kritis), TKBK 3 (kritis) dan TKBK 4 (sangat kritis). Tingkat Kemampuan Berpikir Kritis tersebut disusun berdasarkan 3 macam 
komponen berpikir kritis yaitu (1) elemen bernalar, (2) standar intelektual bernalar dan (3) karakter intelektual bernalar. Namun yang digunakan hanyalah elemen bernalar dan standar intelektual bernalar saja. Hal ini dikarenakan untuk poin ketiga yaitu karakter intelektual bernalar memerlukan waktu bertahun-tahun penelitian untuk bisa mengetahuinya.

Pada penelitian ini, dijumpai peserta didik yang belum mampu menyelesaikan masalah mengenai lingkaran. Karena dari kegiatan tes dan wawancara menunjukkan bahwa peserta didik dalam mengidentifikasi dan menyelesaikan masalah lingkaran berdasarkan informasi berupa data dan fakta yang kurang jelas, tidak tepat, tidak teliti dan tidak relevan. Selain itu, konsep dan ide yang dimiliki kurang jelas, tidak tepat, tidak relevan dan tidak dalam. Bahkan dalam penyimpulan masalah lingkaran tidak jelas dan kurang logis serta sudut pandang yang dimiliki tidak jelas dan terbatas (penyelesaian tunggal). Dari berbagai kriteria yang telah dipaparkan di atas termasuk ke dalam TKBK 0. Tingkat ini dijumpai pada : Soal nomor 3 yang dipenuhi oleh MRS19

Pada penelitian ini, dijumpai peserta didik yang belum mampu menyelesaikan masalah mengenai lingkaran. Karena dari kegiatan tes dan wawancara menunjukkan bahwa peserta didik dalam mengidentifikasi dan menyelesaikan masalah lingkaran berdasarkan informasi berupa data dan fakta yang jelas, tidak tepat, tidak teliti dan tidak relevan. Selain itu, konsep dan ide yang dimiliki jelas, tidak tepat, tidak relevan dan tidak dalam. Bahkan dalam penyimpulan masalah lingkaran tidak jelas dan kurang logis serta sudut pandang yang dimiliki tidak jelas dan terbatas (penyelesaian tunggal). Dari berbagai kriteria yang telah dipaparkan di atas termasuk ke dalam TKBK 1. Tingkat ini dijumpai pada : Soal nomor 1 yang dipenuhi oleh DS09, soal nomor 2 yang dipenuhi oleh MRS19 serta soal nomor 3 yang dipenuhi oleh ANK05 dan KI15

Pada penelitian ini, dijumpai peserta didik yang belum mampu menyelesaikan masalah lingkaran. Peserta didik dalam mengidentifikasi dan menyelesaikan masalah lingkaran berdasarkan informasi berupa data dan fakta yang jelas, tepat, teliti dan relevan. Peserta didik dalam mengidentifikasi dan menyelesaikan masalah lingkaran berdasarkan pada konsep dan ide berupa definisi, konsep, teorema, prinsip dan prosedur yang jelas, tepat, relevan dan dalam. Peserta didik dalam penyimpulan masalah lingkaran tidak jelas dan kurang logis. Peserta didik dalam mengidentifikasi dan menyelesaikan masalah lingkaran berdasarkan sudut pandang yang jelas tetapi terbatas (penyelesaian tunggal). Dari berbagai kriteria yang telah dipaparkan di atas termasuk ke dalam TKBK 2. Tingkat ini dijumpai pada : soal nomor 1 yang dipenuhi oleh, ANK05, CI08 dan KI15 serta soal nomor 2 yang dipenuhi oleh, ANK05, CI08 dan KI15

Pada penelitian ini, dijumpai peserta didik yang mampu menyelesaikan masalah lingkaran. Peserta didik dalam mengidentifikasi dan menyelesaikan masalah lingkaran berdasarkan informasi berupa data dan fakta yang jelas, tepat, teliti dan relevan. Peserta didik dalam mengidentifikasi dan menyelesaikan masalah lingkaran berdasarkan pada konsep dan ide berupa definisi, konsep, teorema, prinsip dan prosedur yang jelas, tepat, relevan dan dalam. Peserta didik dalam penyimpulan masalah lingkaran jelas dan logis. Peserta didik dalam mengidentifikasi dan menyelesaikan masalah lingkaran berdasarkan sudut pandang yang jelas tetapi terbatas (penyelesaian tunggal). Dari berbagai kriteria yang telah dipaparkan di atas termasuk ke dalam TKBK 3. Tingkat ini dijumpai pada : soal nomor 1 yang dipenuhi oleh MRS19, soal nomor 2 yang dipenuhi oleh DS09 serta soal nomor 3 yang dipenuhi oleh CI08 dan DS09.

Hasil penelitian telah dipaparkan di atas, sehingga dari penelitian ini diketahui bahwa kemampuan berpikir kritis dari masing-masing peserta didik berbeda. Selain itu, keuntungan dengan memiliki kemampuan berpikir kritis terutama dalam hal matematika adalah sebagai berikut : (1) Kemampuan ini memungkinkan peserta didik untuk menemukan kebenaran di tengah banjir kejadian dan informasi yang 
mereka hadapi setiap hari. (2) Kemampuan ini merupakan salah satu modal dasar atau modal intelektual yang sangat penting bagi setiap orang dan merupakan bagian yang fundamental dari kematangan manusia. (3) Kemampuan ini mampu melatih peserta didik untuk bersikap rasional serta bertindak atas dasar alasan.

\section{SIMPULAN DAN SARAN}

Dari pembahasan mengenai TKBK yang telah dijumpai oleh peneliti pada siswa kelas VIII-A, jika digabungkan dengan Tahap Berpikir Kritis dalam Matematika adalah sebagai berikut. Tahap klarifikasi, pada tahap ini subjek yang menempati tingkat kemampuan berpikir kritis 1 sampai dengan 2 menunjukkan karakteristik yang hampir sama yaitu mendapatkan informasi dari data yang ada. Subjek mengidentifikasi masalah (pertanyaannya) berdasarkan apa yang tersurat dan tidak menyeluruh. Adapun subjek pada tingkat kemampuan berpikir kritis 3 mampu mengidentifikasi masalah berdasarkan pernyataan yang ada (tersurat) pada masalah secara utuh (kalimat pertanyaan dibaca) dan mengetahui makna yang tersirat pada pertanyaan.

Tahap asesmen, pada tahap ini subjek yang menempati tingkat kemampuan berpikir kritis 1 hanya menggali sebagian kecil informasi yang relevan sedangkan subjek yang menempati tingkat kemampuan berpikir kritis 2 sampai tingkat kemampuan berpikir kritis 3 menggali sebagian besar informasi yang relevan dengan masalah.

Tahap penyimpulan, pada tahap ini subjek yang menempati tingkat kemampuan berpikir kritis 1 sampai tingkat kemampuan berpikir kritis 2 hanya menggunakan berpikir sederhana sedangkan pada tingkat kemampuan berpikir kritis 3 menggunakan berpikir yang lebih luas (sedikit lebih di atas dari pada TKBK 1 dan 2).

Tahap strategi/taktik, subjek yang menempati tingkat kemampuan berpikir kritis 1 menggunakan analogi atau tidak dapat memunculkan strategi yang digunakan. Subjek yang menempati tingkat kemampuan berpikir kritis 2 dan tingkat kemampuan berpikir kritis 3 menggunakan analogi, alur berpikirnya (penalaran) ada yang tidak dapat diikuti dan tidak logis, serta menggunakan pengetahuan yang sudah ada. Subjek pada tingkat kemampuan berpikir kritis 3 menggunakan idenya sendiri dengan mencari hubunganhubungan dalam menyelesaikan masalah, dan alur berpikirnya (penalaran) jelas serta logis.

Adapun saran yang dapat dikemukakan oleh peneliti adalah sebagai berikut.

Bagi peneliti, hendaknya bisa menambah pengetahuan dan pengalaman dalam menerapkan ilmu yang diperoleh dibangku kuliah terhadap masalah yang dihadapi di dunia pendidikan secara nyata dan menjadi bekal di masa mendatang serta bisa melaksanakan penelitian lebih lanjut jika dimungkinkan.

Bagi sekolah, dengan adanya hasil penelitian ini hendaknya dapat dijadikan masukan dan pertimbangan sebagai salah satu bahan alternatif dalam kemajuan semua mata pelajaran terutama matematika serta bisa digunakan acuan untuk lebih meningkatkan kemampuan berpikir kritis siswa.

Bagi guru matematika, ditinjau dari kemampuan kritis siswa hendaknya guru dapat menggunakan metode pengajaran yang tepat guna menunjang peningkatan kualitas belajar mengajar terutama dalam meningkatkan kemampuan berpikir kritis siswa dalam pemecahan masalah matematika.

Bagi peserta didik, hendaknya dapat dijadikan sebagai bekal pengetahuan tentang kemampuan berpikir kritis, sehingga termotivasi untuk selalu memecahkan masalah dengan matang, sungguh-sungguh dan penuh pertimbangan.

Bagi peneliti lain, hendaknya dapat digunakan sebagai acuan dalam penelitian selanjutnya serta memberikan kontribusi bagi upaya peningkatan mutu dan kualitas pendidikan. Namun, penelitian ini hanya melibatkan sedikit sampel yang berarti belum memberikan gambaran yang akurat mengenai tingkat kemampuan berpikir kritis siswa. Oleh karena itu, penelitian lanjutan sangat dimungkinkan untuk melakukan pengujian 
ulang terhadap tingkat kemampuan berpikir kritis siswa dalam pemecahan masalah matematika.

\section{REFERENSI}

Arikunto, Suharsimi. Prof. Dr. 2010. Prosedur Penelitian Suatu Pendekatan Praktek. Jakarta : PT. Rineka Cipta.

Fachrurazi.2011. Penerapan Pembelajaran Berbasis Masalah untuk Meningkatkan Kemampuan Berpikir Kritis dan Komunikasi Matematis Siswa Sekolah Dasar, Edisi Khusus (1). 128

Johnson, Elaine B.2013. Contextual Teaching \& Learning, Bandung: MLC.

Kurniasih, Ary Woro.2010. Penjenjangan Kemampuan Berpikir Kritis dan Identifikasi Tahap Berpikir Kritis Mahasiswa Prodi Pendidikan Matematika FMIPA UNNES dalam Menyelesaikan Masalah Matematika, Malang: Tesis Tidak Diterbitkan.

Lambertuse.2009. Pentingnya Melatih Keterampilan Berpikir Kritis Dalam Pembelajaran Matematika Di SD, dalam Jurnal Forum Kependidikan, Vol 28 (2).

Liliasari.2001. Model Pembelajaran IPA untuk Meningkatkan Keterampilan Berpikir Tingkat Tinggi Calon Guru sebagai Kecenderungan Baru pada Era
Globalisasi, dalam Jurnal Pengajaran MIPA. Vol. 2(1).

Listiawan,Tomi.2014. Pengetahuan Integrasi Teknologi dalam Pembelajaran Calon Guru Matematika Berdasarkan Kerangka TPACK. Disajikan pada Seminar Nasional TEQIP (Teachers Quality Improvement Program) dengan tema "Membangun Karakter Bangsa melalui Pembelajaran Bermakna TEQIP. UM Press

Listiawan, Tomi. 2015. Analisis Technological Content Knowledge (TCK) Calon Guru Matematika Dalam Menggunakan Perangkat Lunak Geometri Dinamis. Disajikan pada seminar nasional matematika dan pendidikan matematika UNY 2015.

Lloyd, Margaret.2010. Thinking Critically about Thinking in Higher Education dalam International Jurnal For The Scholarsip of Teaching and Learning, Vol 4 (2).

Moleong, Lexy J. 2002. Metodologi Penelitian Kualitatif. Bandung: PT Remaja Rosdakarya.

Sugiyono.2009. Metode Penelitian Pendidikan: Kuantitatif, Kualitatif dan $R$ $\& D$.ALFABETA 